\title{
Papaya Ring Spot Virus- Changing the Crop Nature of Papaya from Perennial to Annual- Railway Kodur- A Case Study
}

\author{
D. Srinivasa Reddy ${ }^{1 *}$ and T. Hemadri ${ }^{2}$ \\ ${ }^{1}$ Entomology, Citrus Research Station, AICRP on Fruits (Citrus), Dr.YSRHU, Tirupati- \\ 517502, Chittoor District, AP., India \\ ${ }^{2}$ Entomology, N.S. College of Horticultural Sciences, Affiliated to Dr.YSRHU, Gobburu- \\ 523320, Peddaraveedu, Prakasam District, AP., India
}

*Corresponding author

\begin{tabular}{|l|}
\hline K e y w o r d s \\
$\begin{array}{l}\text { Papaya, Ring spot } \\
\text { virus, Dioecious } \\
\text { Gynodioecious }\end{array}$ \\
\hline Article Info \\
\hline $\begin{array}{l}\text { Accepted: } \\
\text { 15 July } 2019 \\
\text { Available Online: } \\
10 \text { August } 2019\end{array}$ \\
\hline
\end{tabular}

\section{A B S T R A C T}

Papaya is an economical fruit crop in Kadapa district of AP and Kodur region is a traditional belt for cultivation from early 1990's. The cultivation was with dioecious varieties initially and as the time progressed gynodioecious varieties (Taiwan Red lady) were introduced in the Indian market. In Kodur region, the crop directly or indirectly improved the livelihoods of farmers, fruit traders, processing industries, news paper vendors, hoteliers, transporters. The biotic stress disease mainly, Papaya ring spot virus (PRSV) intensity has increased over a period of time due to continuous cultivation of Taiwan Red lady and in majority of the farmers field it has greater impact on yield and was the major reason for reducing the papaya crop from perennial to annual nature which in turn affected different sections of people dependent on this crop. Hence there is a urgent need to introduce varieties showing tolerance to PRSV or shifting to the other crops with equal potential.

\section{Introduction}

Papaya is an economically important crop with its origin at South Mexico and Costa Rica. In India, it is cultivated in an area of about 1.36 lakh hectares with a production of 61.08 lakh tonnes (Anonymous, 2017) and in Andhrapradesh it is majorly grown in Kadapa,
Anantapur, Kurnool, Prakasam and recently Chittoor districts round the year covering an area of 13.56 thousand hectares (Anonymous, 2017). But before the introduction of gynodioecious varieties, the area of papaya in Andhrapradesh was only 6.78 thousand hectares (Anonymous, 2002). In Kadapa district, Kodur region is a traditional belt for 
papaya cultivation where the crop is in cultivation from 1990's. This crop is mainly grown by small and marginal farmers possessing an average land area of less than or equal to 0.25 ha. The initial years of cultivation started with dioecious varieties viz., CO-1, CO-2, Pusa Gaint, Pusa Dwarf etc. and later on in early 2000 (2001 and 2002), farmers shifted from dioecious to gynodioecious varieties mainly with the introduction of gynodioecious cultivar Red Lady by Known-U-Seed Company Ltd of Taiwan. The variety become quite popular among the papaya cultivators within a short period of time due to its tolerant to papaya ring spot virus (Fig. 1), thick red fleshed fruit and possessing $13 \%$ TSS. It is also an excellent shipper means showing good shelf life for long distance transport and also been ideal for local market and processing. The area under cultivation increased many folds in Kodur region where it paved the route for small and marginal farmers to improve their livelihoods and for other sections of people (farm labourers, fruit traders), processing industries (Bakeries and Confectionaries, Cosmetic etc.), news paper vendors, hoteliers, transporters etc. directly or indirectly started depending on papaya cultivation in the region (Chart 1).

\section{Farmers}

Most of the farmers in Kodur region are small and marginal farmers and shifted cultivation practice from dioecious varieties (CO-1, CO2) to gynodioecious varieties by maintaining a plant population of 1200 plants of Red Lady cultivar with a plant spacing of $1.8 \mathrm{~m} \times 1.8 \mathrm{~m}$. In early twentieth century, with the introduction of this variety in the region, the yield was 100-120 tonnes per acre (three harvests over a period of 2.5-3 years) and farmers achieved a net profit of Rs 1,20,000 to $1,50,000$ per acre though the market price of fruit was only Rs. 1500 per tonne. But later on due to continuous cultivation of the same variety in the same piece of land, the net profit margin decreased several folds viz., in 201718 , the crop gave only Rs. 20,000 to 45,000 per acre with a production of 20-25 tonnes/acre. The one interesting observation is the market price has increased manyfolds over a period of cultivation time for example in 2017-18, an average price is Rs. 5,000/tonne of fruit as compared to previous year (Table $1)$.

\section{Nursery growers}

Apart from farmers, nursery growers also benefited from raising of papaya seedlings and charged between Rs 2.50 to 3.00 per seedling (2017-18 price) only to care the plant for a period of 45 days after the farmers handed over the seed material to nursery men.

\section{Farm labourers}

Papaya nursery and main field cultivation has given equal employment opportunity to both men and women for many works viz., planting, weeding, harvests, milky latex (papain) extraction etc.

\section{Hotels}

Hotels are also benefited in the aspects of providing accommodation to traders.

\section{Fruit traders}

Traders directly purchase fruits from farmers and send the produce to distant markets viz., Mumbai, Madhya Pradesh, Rajasthan, Delhi etc and semi-ripened fruits are sold to Bakeries and Confectionery, Cosmetic industries and in turn get as commission from the whole sale mandis or processors.

\section{Transporters}

Transporters are benefited from exporting the fruits to long distant markets. The 
transportation cost was Rs. 45,000/- for 16 tonnes (Cost of transport per kilogram is Rs. 3/-) load to Delhi in 2009-10 and now it is Rs. 90,000/- for 16 tonnes load (Cost of transport per kilogram is Rs. 6 - 6.50/-) and the reason for this price rise drastically is due to surge in fuel prices.

\section{News paper vendors}

The quality newspaper especially English newspaper is used for packing the fruit for long distant transport due to which the vendors gets business. In the year 2001, the cost of paper was Rs.4-6 per kg, in 2011 it was
Rs. $11 / \mathrm{kg}$ and in 2017 it is Rs. 23 per $\mathrm{kg}$ and on an average, to pack 16 tonnes of fruit, 250 $\mathrm{kg}$ of newspaper is required.

\section{Papain extraction (Unripened fruits)}

The contract farming system exists is like contract farming where a set of labour extracts the papain latex from the unripened fruit and the cost of milky latex is 120/- per kilogram.

In this way the papaya crop gives a fruitful of employment to all categories of people.

Table.1 Comparison of production cost and net profits of papaya cv, Red lady in 2001-02 and 2017-18

\begin{tabular}{|l|l|l|l|l|l|l|}
\hline Year & $\begin{array}{l}\text { Area } \\
\text { (acre) }\end{array}$ & $\begin{array}{l}\text { total yield } \\
\text { (tonnes/acre) }\end{array}$ & $\begin{array}{l}\text { Total cost of } \\
\text { cultivation } \\
\text { (Rs/acre) }\end{array}$ & $\begin{array}{l}\text { Market } \\
\text { price } \\
\text { (Rs/tonne) }\end{array}$ & $\begin{array}{l}\text { Gross Profit } \\
\text { (Rs. /acre) }\end{array}$ & Net Profit \\
\hline $\mathbf{2 0 0 1 - 2 0 0 2}$ & 1.0 & $100-120^{*}$ & $30,000-40,000 /-$ & $1500-00$ & $150000-180000$ & $120000-150000$ \\
\hline $\mathbf{2 0 1 7 - 2 0 1 8}$ & 1.0 & $20-25 \downarrow$ & $80,000 /-\uparrow$ & $5000-00 \uparrow$ & $100000-12500 \downarrow$ & $20000-45000 \downarrow$ \\
\hline
\end{tabular}

Chart.1 Section of people directly or indirectly dependent on papaya cultivation

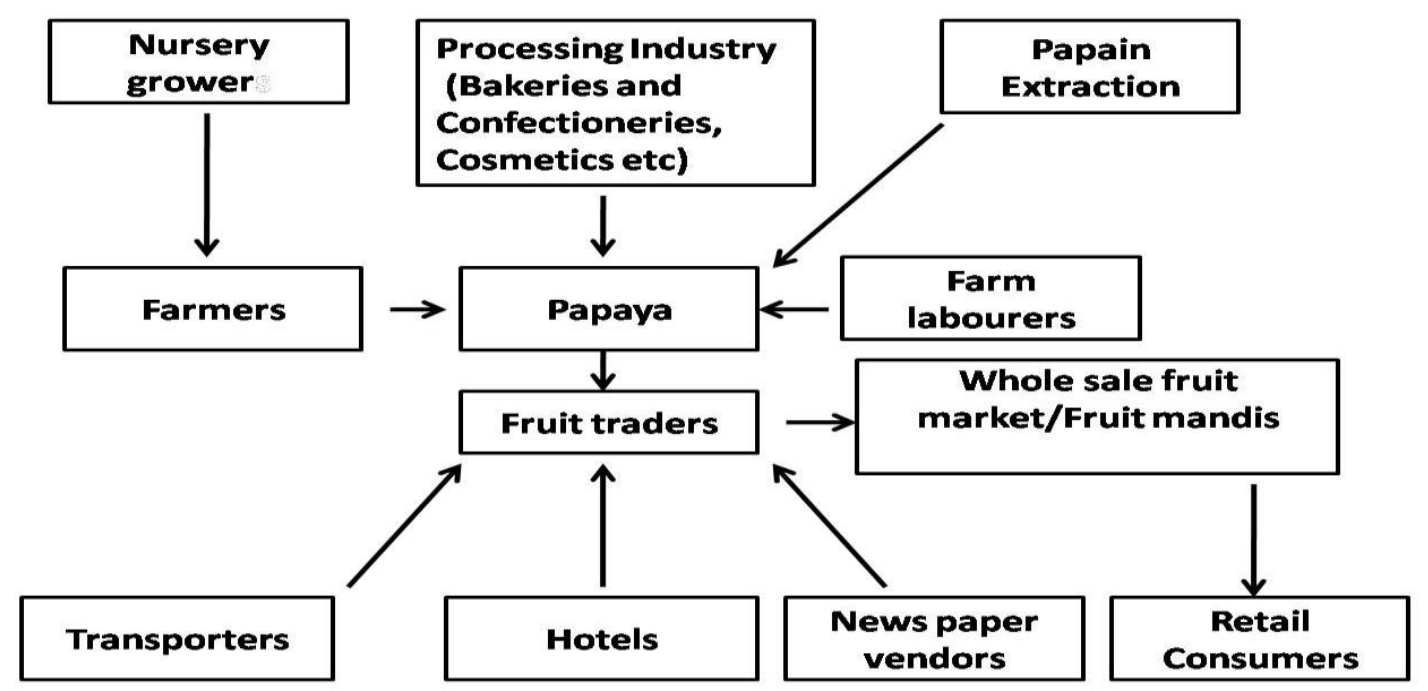


Fig.1 Healthy papaya crop cv. Red Lady in the early $20^{\text {th }}$ Century (2002)

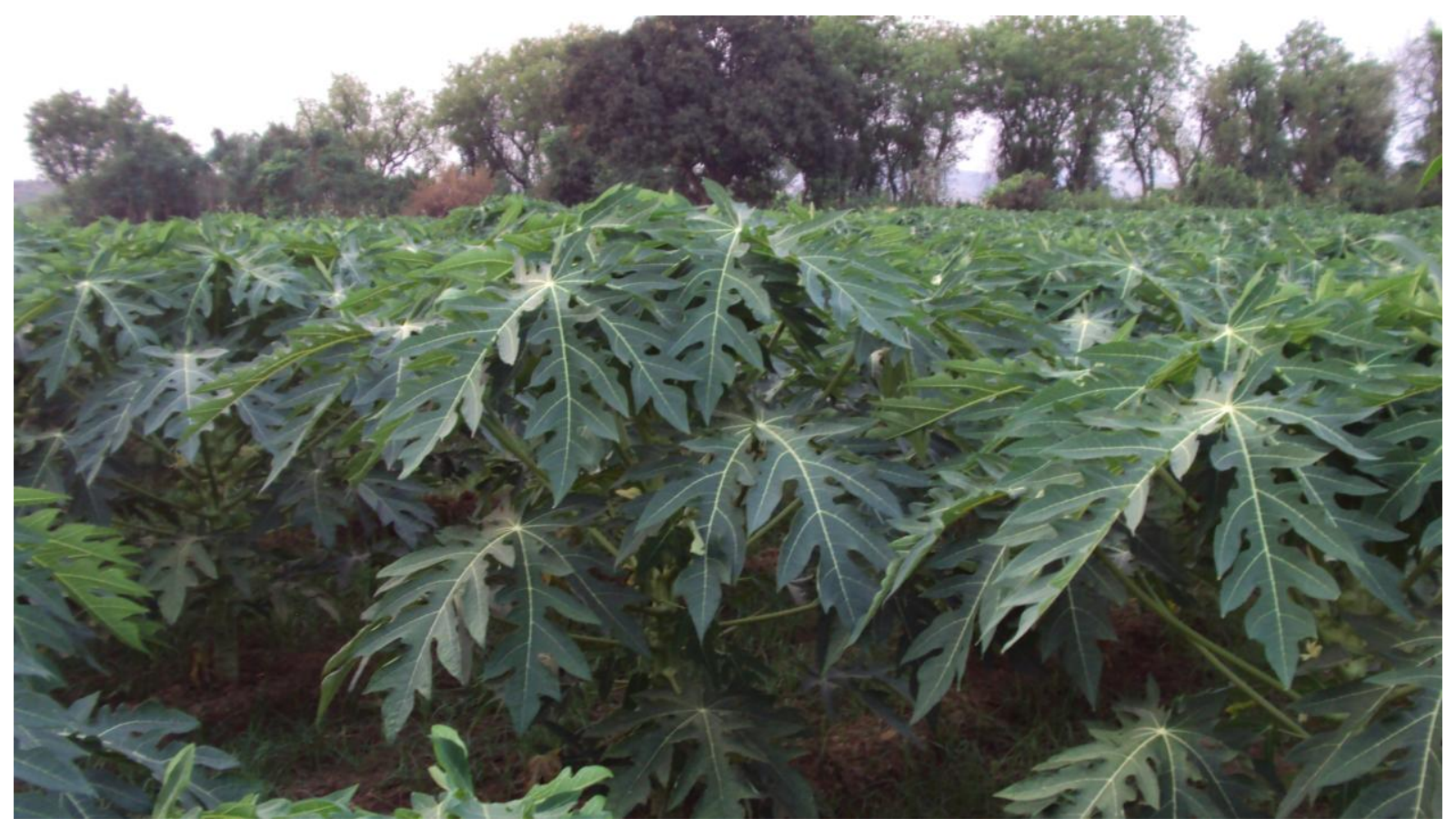

Fig.2 PRSV infected papaya crop cv. Red Lady in 2017-18 season

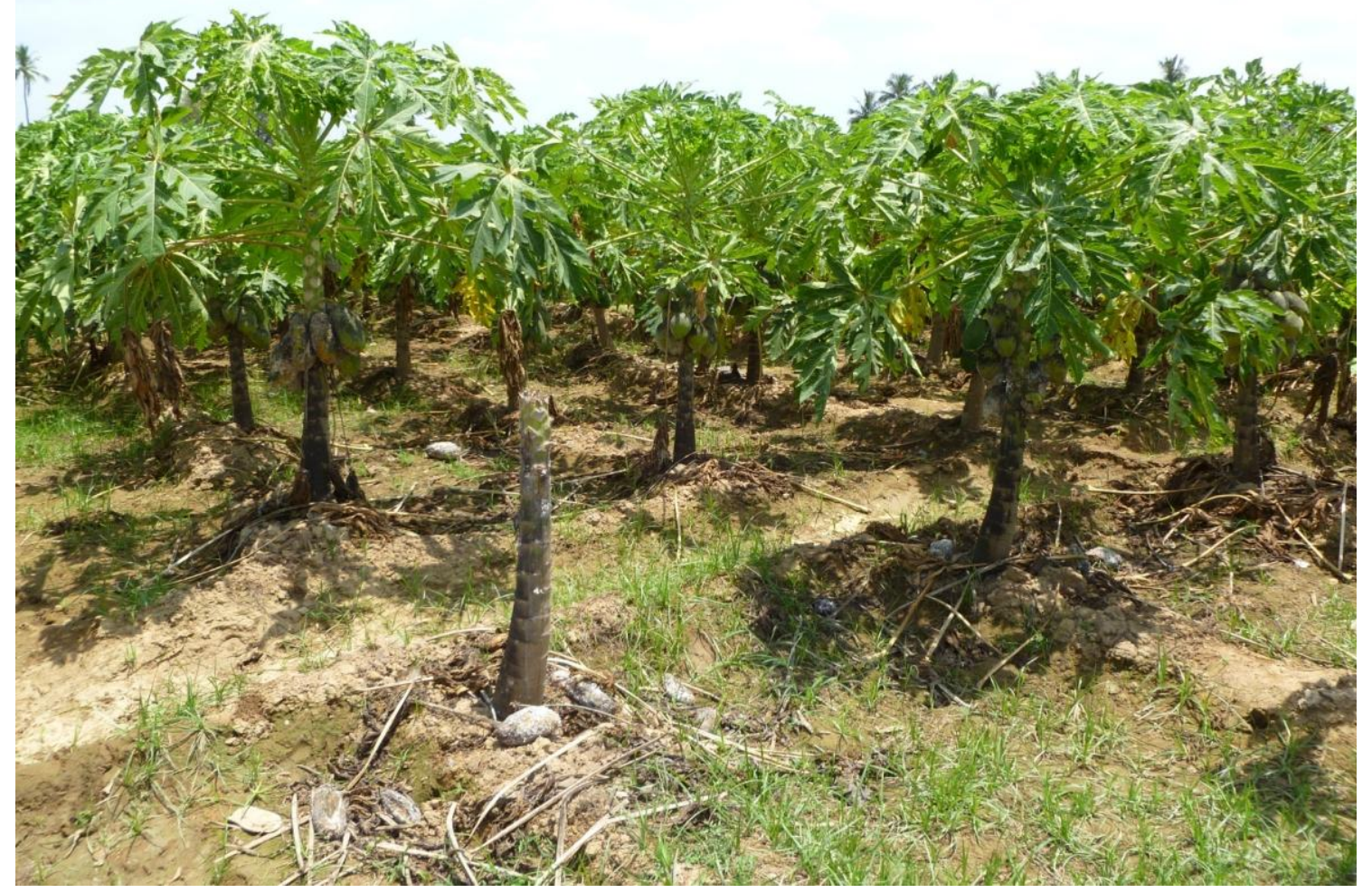


It is concluded, by the comparative study in the early $20^{\text {th }}$ century (2001) and today's scenario (2017-18), the disease mainly Papaya ring spot virus incidence which is not seed transmitted but insect vectors (aphid Aphis gossypii, A. craccivora, and Myzus persicae) play a major role in transmission the disease intensity has increased over a period of time due to continuous cultivation of Taiwan Red lady and 100 percent infection can be observed in the majority of the farmers field affecting the yield (Fig. 2). The disease also has lead to the total crop failure though crop protection input share has taken a major share in terms of cost of cultivation of the papaya crop in the region. The different approaches adopted for managing this disease viz., border crop, vector management through insecticides sprays, micronutrients application have not been practically successful in farmers field where this very particular disease has been, was and will be the major cause for changing the papaya crop from perennial (2.5-3.0 years in early introduction) to annual nature $(<9$ months in 2017-18 cropping season) affecting the different sections of people dependent on this crop. So, in this regard there is a very urgent need to introduce other gynodioecious varieties showing tolerance to PRSV or shifting to the other crops or declaring a crop holiday for a certain period of time so that the farmers earning per capita increases.

\section{References}

Anonymous, 2014, Indian Horticulture database. Ministry of Agriculture, Government of India 85, Institutional Area, Sector-18, Gurgaon - 122 015, pp. 103.

\section{How to cite this article:}

Srinivasa Reddy, D. and Hemadri, T. 2019. Papaya Ring Spot Virus- Changing the Crop Nature of Papaya from Perennial to Annual- Railway Kodur- A Case Study. Int.J.Curr.Microbiol.App.Sci. 8(09): 448-452. doi: https://doi.org/10.20546/ijcmas.2019.809.054 